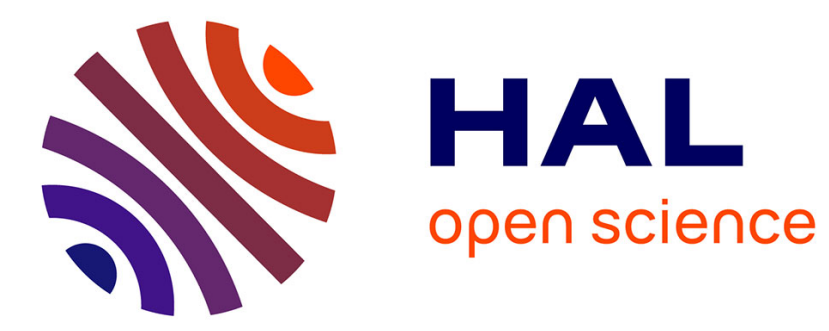

\title{
Rates of magma transfer in the crust: Insights into magma reservoir recharge and pluton growth
}

\author{
Thierry Menand, Catherine Annen, Michel de Saint Blanquat
}

\section{To cite this version:}

Thierry Menand, Catherine Annen, Michel de Saint Blanquat. Rates of magma transfer in the crust: Insights into magma reservoir recharge and pluton growth. Geology, 2015, 43 (3), pp.199202. $10.1130 / G 36224.1$. hal-03025421v2

\section{HAL Id: hal-03025421 \\ https://hal.science/hal-03025421v2}

Submitted on 26 Nov 2020

HAL is a multi-disciplinary open access archive for the deposit and dissemination of scientific research documents, whether they are published or not. The documents may come from teaching and research institutions in France or abroad, or from public or private research centers.
L'archive ouverte pluridisciplinaire HAL, est destinée au dépôt et à la diffusion de documents scientifiques de niveau recherche, publiés ou non, émanant des établissements d'enseignement et de recherche français ou étrangers, des laboratoires publics ou privés. 


\title{
Rates of magma transfer in the crust: Insights into magma reservoir recharge and pluton growth
}

\author{
Thierry Menand ${ }^{1}$, Catherine Annen ${ }^{2}$, and Michel de Saint Blanquat ${ }^{3}$ \\ 'Laboratoire Magmas et Volcans, Université Blaise Pascal-CNRS-IRD, OPGC, 5 rue Kessler, 63038 Clermont-Ferrand, France \\ ${ }^{2}$ School of Earth Sciences, University of Bristol, Wills Memorial Building, Bristol BS8 1RJ, UK \\ ${ }^{3}$ Geosciences Environnement Toulouse, Université de Toulouse, CNRS, IRD, OMP, 14 avenue Edouard-Belin, 31400 Toulouse, France
}

\begin{abstract}
Plutons have long been viewed as crystallized remnants of large magma reservoirs, a concept now challenged by high-precision geochronological data coupled with thermal models. Similarly, the classical view of silicic eruptions fed by long-lived magma reservoirs that slowly differentiate between mafic recharges is being questioned by petrological and geophysical studies. In both cases, a key and yet unresolved issue is the rate of magma transfer in the crust. Here, we use thermal analysis of magma transport to calculate the minimum rate of magma transfer through dikes. We find that unless the crust is exceptionally hot, the recharge of magma reservoirs requires a magma supply rate of at least $\sim 0.01 \mathrm{~km}^{3} / \mathrm{yr}$, much higher than the long-term growth rate of plutons, which demonstrates unequivocally that igneous bodies must grow incrementally. This analysis argues also that magma reservoirs are short lived and erupt rapidly after being recharged by already-differentiated magma. These findings have significant implications for the monitoring of dormant volcanic systems and our ability to interpret geodetic surface signals related to incipient eruptions.
\end{abstract}

\section{INTRODUCTION}

Petrological and geophysical studies challenge the long-held view that silicic magma reservoirs are long lived, differentiating slowly between mafic recharges. For example, until recently, Santorini volcano, Greece, was understood as a volcano whose shallow dacitic reservoir is regularly recharged by small mafic spurts (Martin et al., 2008). However, crystal diffusion chronometry and surface deformation data reveal a different story. In the case of the ca. 1600 B.C. Minoan caldera-forming eruption, reactivation was fast $(<100 \mathrm{yr})$ with a transient recharge flux of $>0.05 \mathrm{~km}^{3} / \mathrm{yr}$, more than 50 times the long-term magma influx that feeds the volcano (Druitt et al., 2012). Crucially, reactivation represented a sizable proportion of the shallow reservoir, and involved an already-differentiated magma of deep origin (Druitt et al., 2012). Similar conclusions are reached for Santorini's recent activity (Parks et al., 2012). The emerging view is thus of a volcano whose shallow reservoir is regularly replenished from depth by high-flux batches of already-differentiated magma, the duration of which is much shorter than that of intervening repose periods. These findings raise key but unresolved questions: What determines the recharge rate of shallow reservoirs? And ultimately, can we identify recharges that will lead to an eruption? These are crucial issues in volcanology, and not simply at Santorini.

These issues also echo that of the rates at which pluton assembly occurs (Petford et al., 2000; Cruden and McCaffrey, 2001; Glazner et al., 2004; de Saint Blanquat et al., 2011). Indeed, the example of Santorini fits with models for the generation of evolved magmas in deep crustal hot zones (Annen et al., 2006) and the incremental emplacement and growth of igneous bodies in the upper crust (Menand et al., 2011). According to the deep-hot-zone model (Annen et al., 2006), the chemical diversity of arc magmas and granites is generated in the lower crust. After leaving their deep hot zones, the vast majority of magmas stall below the surface, many of them as sills and commonly amalgamating together to form larger plutons as evidenced by geological, geophysical, and geochronological data (e.g., Hawkes and Hawkes, 1933; Cruden, 1998, 2006; Benn et al., 1999; de Saint Blanquat et al., 2001; Al-Kindi et al., 2003; Michel et al., 2008;
Horsman et al., 2009; Leuthold et al., 2012). It is in the upper crust that magmas acquire their textural diversity owing to shallow-level crystallization. Incremental growth of plutons is widely accepted, and the issue is now to identify the incremental processes involved and to quantify their rates. The recharge of volcano reservoirs and the growth of plutons seem intimately related: in both cases, the key point is the rate of magma transfer between a source and a shallower storage level.

\section{THERMAL ANALYSIS}

Magma transport in the crust occurs mainly through dikes (Lister and Kerr, 1991; Clemens and Mawer, 1992; Petford et al., 1993), but there is currently no three-dimensional, time-dependent propagation model. We therefore focused our analysis on the steady-state propagation of buoyant dikes, and performed a stochastic thermal analysis to quantify the minimum volumetric flow rates that are required for dikes to transport magma through Earth's crust.

Dikes need to propagate fast enough through the crust to avoid death by solidification (Spence and Turcotte, 1985; Rubin, 1995). Flowing magma advects heat along dikes while heat is conducted away by the colder country rocks. If advection is slower than conduction, then the magma will solidify and dike propagation will cease. A buoyant dike intruding rocks of fracture toughness $K_{\mathrm{c}}$ over some height $H$ must thus be fed with a critical minimum magma supply rate, $Q_{\mathrm{c}}$ (details are provided in the GSA Data Repository ${ }^{1}$ ):

$$
Q_{\mathrm{c}}=\frac{9}{32}\left[\frac{C_{\mathrm{p}}\left(T_{\mathrm{f}}-T_{\infty}\right)^{2}}{L\left(T_{0}-T_{\mathrm{f}}\right)}\right]^{9 / 4}\left(\frac{\Delta \rho g \kappa^{3} H^{3}}{\mu}\right)^{1 / 4}\left(\frac{K_{\mathrm{c}}}{\Delta \rho g}\right)^{2 / 3},
$$

where $L$ is magma latent heat, $C_{\mathrm{p}}$ is its specific heat capacity, $T_{0}, T_{\mathrm{f}}$, and $T_{\infty}$ are initial magma temperature, freezing temperature, and crustal far-field temperature, respectively, $\mu$ is magma dynamic viscosity, $\kappa$ is its thermal diffusivity, $\Delta \rho$ is the density difference between country rocks and magma, and $g$ is gravitational acceleration. This is the minimum influx of magma a buoyant dike needs to propagate over a height $H$ without freezing. A growing pluton would need to be fed with at least this influx of magma $Q_{\mathrm{c}}$, which would thus represent a short-term magma supply rate, otherwise its feeder dike would freeze before it could reach this emplacement level. The same goes for the recharge of an existing reservoir lying a height $H$ above a deeper magma source; $Q_{\mathrm{c}}$ would then represent a shortterm magma recharge or replenishment rate.

\section{RESULTS}

We used Monte Carlo simulations to calculate the expected range of critical rates for magmas with viscosities between 10 and $10^{8} \mathrm{~Pa} \cdot \mathrm{s}$. Magmatic and country-rock parameters were sampled randomly, and three different ranges of far-field temperatures $T_{\infty}$ were tested: cold, intermediate, or hot crusts (Table 1). In each case, $T_{\infty}$ was kept constant throughout the

${ }^{1}$ GSA Data Repository item 2015072, supplemental information, is available online at www.geosociety.org/pubs/ft2015.htm, or on request from editing@ geosociety.org or Documents Secretary, GSA, P.O. Box 9140, Boulder, CO 80301, USA. 
TABLE 1. PARAMETER RANGES AND DISTRIBUTIONS USED IN MONTE CARLO SIMULATIONS

\begin{tabular}{lcccc}
\hline \hline Parameter & Distribution & Min & Max & Mean \\
\hline Magma viscosity $(\mathrm{Pa} \cdot \mathrm{s})$ & Uniform & 10 & $10^{8}$ & - \\
Latent heat, $L(\mathrm{~J} / \mathrm{kg})^{\mathrm{a}, \mathrm{b}, \mathrm{c}}$ & Uniform & $2.5 \times 10^{5}$ & $5.5 \times 10^{5}$ & - \\
Specific heat, $C_{\mathrm{p}}(\mathrm{J} / \mathrm{kg} \mathrm{K})^{\mathrm{a}, \mathrm{d}}$ & Uniform & 800 & 1600 & - \\
Thermal diffusivity, $\mathrm{\kappa}\left(\mathrm{m}^{2} / \mathrm{s}\right)^{\mathrm{e}}$ & Uniform & $0.3 \times 10^{-6}$ & $2.0 \times 10^{-6}$ & - \\
Fracture toughness, $K_{\mathrm{c}}\left(\mathrm{Pa} \mathrm{m}^{1 / 2}\right)^{\mathrm{g}, \mathrm{ghh}}$ & Log-normal & $10^{6}$ & $10^{9}$ & $10^{7.5}$ \\
Density contrast, $\Delta \rho\left(\mathrm{kg} / \mathrm{m}^{3}\right)^{\mathrm{i}}$ & Uniform & 100 & 700 & - \\
Magma temperature, $T_{0}\left({ }^{\circ} \mathrm{C}\right)^{\mathrm{j}}$ & Uniform & 750 & 1250 & - \\
Freezing temperature, & & & & \\
$T_{\mathrm{f}}=T_{0}-\Delta T_{\mathrm{i}} \cdot \Delta T_{\mathrm{i}}\left({ }^{\circ} \mathrm{C}\right)^{\mathrm{k}, \mathrm{l}}$ & Uniform & 20 & 200 & - \\
Far field temperature, $T_{\infty}\left({ }^{\circ} \mathrm{C}\right):$ & & & & \\
$\quad$ Cold crust & Uniform & 50 & 200 & - \\
$\quad$ Intermediate crust & Uniform & 200 & 400 & - \\
$\quad$ Hot crust & Uniform & 400 & 600 & - \\
\hline
\end{tabular}

Note: The (Maximum - Minimum) range of the $\log (K)$ normal distribution was equated with six standard deviations. References: a-Bohrson and Spera (2001); b-Kojitani and Akaogi (1994); c-Lange et al. (1994); d-Robertson (1988); e-Whittington et al. (2009); f-Atkinson (1984); g-Delaney and Pollard (1981); h-Heimpel and Olson (1994); i-Spera (2000); j-Mysen (1981); k—Piwinskii and Wyllie (1968); - -Wagner et al. (1995).

crust, a simplification (no geothermal gradient) that may underestimate magma heat lost, hence $Q_{\text {c }}$.

Figure 1A shows the range of critical short-term supply rates $Q_{\mathrm{c}}$ as a function of magma viscosity from 10,000 Monte Carlo simulations for a 5-km-high dike in a crust with intermediate far-field temperature $\left(T_{\infty}=\right.$ $200-400{ }^{\circ} \mathrm{C}$ ). For all magma viscosities, the simulations give a range of $Q$ with a normal distribution around a mean value on a logarithmic scale (Fig. 1B). This allows a minimum supply rate to be defined, $Q_{\text {cmin }}$, three standard deviations below the mean value; statistically, more than $99 \%$ of the calculated rates lie above $Q_{\text {cmin }}$ (Fig. 1).

Figure 2 shows this minimum supply rate $Q_{\text {cmin }}$ as a function of magma viscosity for two dike heights, $5 \mathrm{~km}$ and $30 \mathrm{~km}$, and various far-field temperatures. $Q_{\text {cmin }}$ decreases with increasing magma viscosity: fluid dynamics dictate that more viscous magmas induce thicker dikes, and because thicker dikes cool more slowly, the net effect is a lower minimum supply rate (see details in the Data Repository). Hotter crusts lead to lower amounts of heat loss, hence lower minimum supply rates; this nonlinear effect can reduce $Q_{\text {cmin }}$ by several orders of magnitude. Longer propagation heights require higher $Q_{\text {cmin }}$. For the most conservative scenario of dikes propagating over 5 $\mathrm{km}$ in a hot crust $\left(T_{\infty}=400-600{ }^{\circ} \mathrm{C}\right)$, a minimum supply rate of $10^{-4}$ to $4 \times$ $10^{-3} \mathrm{~km}^{3} / \mathrm{yr}$ is required to transport magmas with viscosities between 10 and $10^{8} \mathrm{~Pa} \cdot \mathrm{s}$ (Fig. 2). Longer magma-transport heights and colder environments $\left(T_{\infty}<400{ }^{\circ} \mathrm{C}\right)$ lead to higher minimum supply rates $\left(>0.01 \mathrm{~km}^{3} / \mathrm{yr}\right)$.

Figure 3 compares the density distribution of all of the critical shortterm supply rates $Q_{\mathrm{c}}$ calculated by Monte Carlo simulations with the density distribution of 47 published maximum, long-term-averaged, plutonfilling-rate estimates (Table DR1 in the Data Repository). There is a clear dichotomy between pluton-filling rates and our critical short-term supply rates, which has several important implications. First, irrespective of pluton emplacement depth, magma composition, and tectonic setting, nearly all of the reported plutons have too low a magma supply rate to have formed by a single episode of magma injection. This means that the formation of these plutons must have involved successive, discrete magma pulses with a short-term injection rate for their successive feeder dikes of at least $\sim 0.01$ $\mathrm{km}^{3} / \mathrm{yr}$ (Fig. 3). We note that some of the few reported filling-rate estimates greater than $0.01 \mathrm{~km}^{3} / \mathrm{yr}$ exhibit strong evidence for incremental growth (e.g., Papoose Flat pluton, California; de Saint Blanquat et al., 2001) or are associated with particularly hot crusts (e.g., Japan [Tanaka and Ishikawa, 2002], Socorro magma body, New Mexico [Reiter et al., 2010]), in agreement with our findings that hotter crusts allow magma transport in dikes at much lower flow rates (Fig. 2). Moreover, most of the larger estimated filling rates are derived from observations of surface deformation inte-
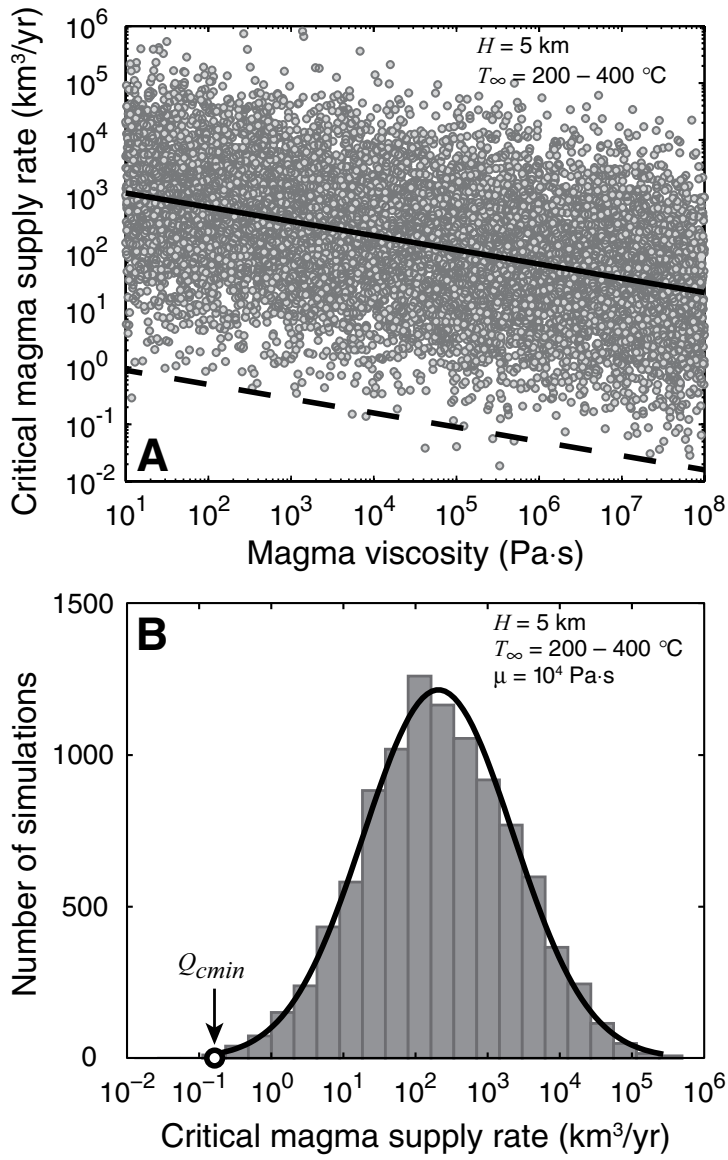

Figure 1. Critical magma supply rates $Q_{c}$ from 10,000 Monte Carlo simulations for 5-km-high $(H)$ buoyant dike in intermediate crust (far-field temperature, $T_{\infty}=200$ $\left.400{ }^{\circ} \mathrm{C}\right)$. A: Range of $Q_{\mathrm{c}}$ as function of magma viscosity. Continuous black curve is mean $Q_{c}$. Dashed black curve is minimum critical supply rate, $Q_{\text {cmin }}$, defined as the mean $Q_{c}$ minus three standard deviations. B: Histogram of Monte Carlo simulations for magma viscosity $(\mu)$ of $10^{4} \mathrm{~Pa} \cdot \mathrm{s}$. On a logarithmic scale, this histogram is well fitted by a normal distribution with mean of 2.32 and standard deviation of 1.04 , hence $Q_{\mathrm{cmin}} \sim 0.16 \mathrm{~km}^{3} / \mathrm{yr}$.

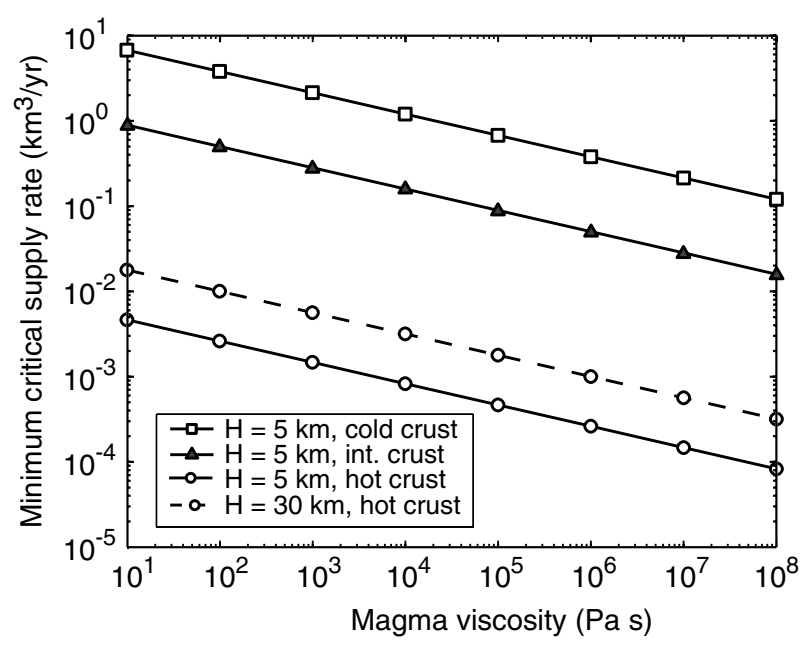

Figure 2. Minimum magma influx, $Q_{\mathrm{cmin}}$, to prevent magma freeze. Two vertical propagation distances are considered $(5 \mathrm{~km}$, continuous line; $30 \mathrm{~km}$, dashed line) as function of magma viscosity and far-field temperature, $T_{\infty}$ (squares: $T_{\infty}=50-200^{\circ} \mathrm{C}$; triangles: $T_{\infty}=200-400^{\circ} \mathrm{C}$; circles: $\left.T_{\infty}^{\infty}=400-600^{\circ} \mathrm{C}\right)$. int.-intermediate. 


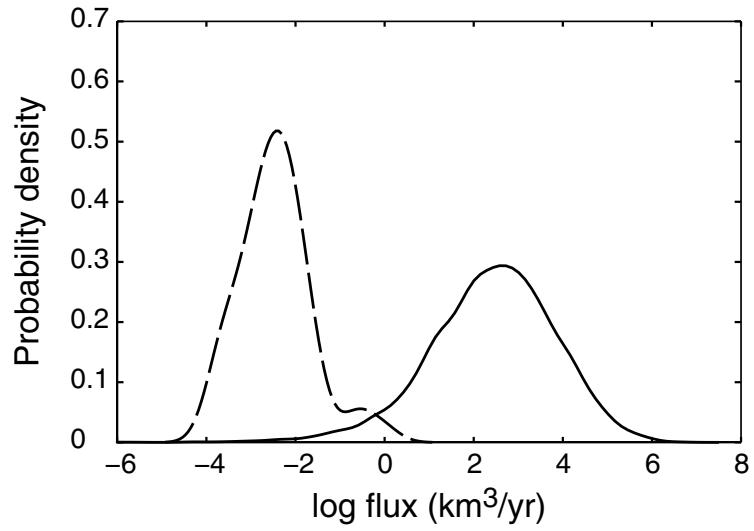

Figure 3. Probability density estimates (normal kernel function) of $\mathbf{4 7}$ maximum, long-term-averaged pluton-filling rates (dashed curve; Table DR1 [see footnote 1]) and of 10,000 Monte Carlo critical magma supply rates, $Q_{c}$ (continuous curve; parameter ranges in Table 1, far-field temperatures, $T_{\infty}$, sampled according to sampled dike heights [between 5 and $30 \mathrm{~km}$ ]: $T_{\infty}=400-600{ }^{\circ} \mathrm{C}$ for heights $>20 \mathrm{~km}, T_{\infty}=200$ $600{ }^{\circ} \mathrm{C}$ for heights $>10 \mathrm{~km}, T_{\infty}=50-600^{\circ} \mathrm{C}$ for shorter dikes).

grated over at most two decades; they should be close to short-term supply rates and are indeed in agreement with our minimum fluxes. Second, $Q_{\text {cmin }}$ should also be the absolute minimum short-term recharge rate of magma reservoirs, such as that of Santorini volcano. A value of $\sim 0.01 \mathrm{~km}^{3} / \mathrm{yr}$ is in agreement with the recharge rates estimated for the Minoan eruption or the current activity at Nea Kameni, Greece (Druitt et al., 2012; Parks et al., 2012), as well as the latest estimates for the recent magma supply or recharge rates at Lazufre volcanic complex in the central Andes Mountains (Remy et al., 2014). Estimates determined for time scales of one to several decades (Lazufre, Santorini) probably integrate repose periods. Discrete recharge rates are likely to be larger (Usu-san and Syowa Sinzan, Japan). Finally, filling rates based on deformation are typically one order of magnitude larger than those based on geochronology (Table DR1), suggesting intermittent feeding over various time scales.

\section{IMPLICATIONS}

According to our thermal analysis, the feeding of volcanoes by magmas from depth requires a short-term supply rate greater than $\sim 0.01 \mathrm{~km}^{3}$ / yr. However, a storage region can develop into a potentially active reservoir with a sizeable amount of eruptible magma only if the time-averaged supply rate exceeds $0.001-0.01 \mathrm{~km}^{3} / \mathrm{yr}$ (Annen, 2009). For lower time-averaged supply rates, the volume of eruptible magma available at any one time is at best that of a single magmatic recharge event. Because most igneous bodies are emplaced at low time-averaged rates (Fig. 3), large eruptions require that either the repose time between recharges becomes transiently shorter, leading to a sharp increase in magma influx (Schöpa and Annen, 2013), or a recharge is exceptionally prolonged and rapidly brings in a large volume of magma that is erupted shortly after the intrusive event.

Evidence for rapid short-term recharge rates is not restricted to Santorini volcano. According to element diffusion models, the $530 \mathrm{~km}^{3}$ of silicic magma erupted during the Oruanui (New Zealand) eruption had been assembled within $\sim 1600 \mathrm{yr}$, implying an average flux of at least 0.3 $\mathrm{km}^{3} / \mathrm{yr}$, and most of the erupted volume was injected $\sim 200 \mathrm{yr}$ before the eruption (Allan et al., 2013). Similarly, quartz crystallization times in the Bishop tuff magma (California) are estimated to have occurred within 500-3000 yr before eruption (Gualda et al., 2012). From these data and our analysis, we suggest that long-lived magma bodies in the middle or deep crust feed ephemeral shallow reservoirs that erupt shortly after their formation over a few centuries or millennia. Because there are long periods of no or low activity between such magmatic high-flux feeding episodes, the long-term construction rate of plutons assembled from intrusions that failed to feed a shallower reservoir or to erupt is much lower than the reservoir assembly rate recorded by erupted crystals. This sporadic assembly must occur at several levels in the lower and upper crust; from mass balance, because only part of the magma stored in a reservoir continues toward the surface, we expect long-term fluxes to decrease for successively shallower reservoirs. Magma reservoirs can be long lived in the deep crust because of higher ambient temperature, whereas in the cold shallow crust, magmas that do not erupt shortly after emplacement solidify rapidly. Moreover, magmas emplaced at high rates relatively close to the surface may induce such high stresses in the cold, brittle crust that eruption is almost unavoidable (Jellinek and DePaolo, 2003).

Our analysis raises the question of our ability to interpret geodetic surface signals: differentiating between surface deformation produced by an new influx of magma bound to form a frozen pluton, and that associated with a reservoir recharge, when both scenarios require the same minimum short-term magma influx. Which parameters do we need to determine in order to make such a distinction? Our analysis implies that one cannot tell from a single magma pulse what will happen next: a pulse must have a minimum short-term flux in order to be thermally viable whatever the thermal fate of the storage region it might be feeding (pluton or volcanic reservoir). However, a key point is that the fate of this storage region hinges upon its time-averaged supply rate, integrated over several magma pulses (Annen, 2009; Schöpa and Annen, 2013). Diffusion chronometry provides access to time scales that are commensurate with the fast emplacement rates of magma intrusions but requires material that has already been erupted. Continuous geodetic measurements of volcano surface deformation (e.g., Remy et al., 2014) could provide a means to estimate recharge volumes and rates integrated over several magma pulses, and thus the potential to discriminate between magmatic intrusions bound to crystallize, owing to a too-slow time-averaged supply rate, and those recharging a reservoir at fast enough rates to potentially lead to future eruptions.

\section{ACKNOWLEDGMENTS}

We thank A.R. Cruden, Allen Glazner, and an anonymous reviewer for their thorough and critical reviews. We acknowledge support from a chaire mixte IRDUBP, ERC Advanced Grants "CRITMAG" and "VOLDIES", and the CNRSINSU program Syster. This research was performed as part of the IRD Laboratoire Mixte International SVAN, and was partially funded by the French Government Laboratory of Excellence initiative ANR-10-LABX-0006, the Région Auvergne, and the European Regional Development Fund. This is Laboratory of Excellence ClerVolc contribution number 130.

\section{REFERENCES CITED}

Al-Kindi, S., White, N., Sinha, M., England, R., and Tiley, R., 2003, Crustal trace of a hot convective sheet: Geology, v. 31, p. 207-210, doi:10.1130/0091 -7613(2003)031<0207:CTOAHC >2.0.CO;2.

Allan, A.S.R., Morgan, D.J., Wilson, C.J.N., and Millet, M.-A., 2013, From mush to eruption in centuries: Assembly of the super-sized Oruanui magma body: Contributions to Mineralogy and Petrology, v. 166, p. 143-164, doi:10.1007 /s00410-013-0869-2.

Annen, C., 2009, From plutons to magma chambers: Thermal constraints on the accumulation of eruptible silicic magma in the upper crust: Earth and Planetary Science Letters, v. 284, p. 409-416, doi:10.1016/j.eps1.2009.05.006.

Annen, C., Blundy, J.D., and Sparks, R.S.J., 2006, The genesis of intermediate and silicic magmas in deep crustal hot zones: Journal of Petrology, v. 47, p. 505-539, doi:10.1093/petrology/egi084.

Atkinson, B.K., 1984, Subcritical crack growth in geological materials: Journal of Geophysical Research, v. 89, p. 4077-4114, doi:10.1029/JB089iB06p04077.

Benn, K., Roest, W.R., Rochette, P., Evans, N.G., and Pignotta, G.S., 1999, Geophysical and structural signatures of syntectonic batholith construction: The South Mountain Batholith, Meguma Terrane, Nova Scotia: Geophysical Journal International, v. 136, p. 144-158, doi:10.1046/j.1365-246X.1999.00700.x.

Bohrson, W.A., and Spera, F.J., 2001, Energy-constrained open-system magmatic processes II: Application of energy-constrained assimilation-fractional crystallization (EC-AFC) model to magmatic systems: Journal of Petrology, v. 42, p. 1019-1041, doi:10.1093/petrology/42.5.1019.

Clemens, J.D., and Mawer, C.K., 1992, Granitic magma transport by fracture propagation: Tectonophysics, v. 204, p. 339-360, doi:10.1016/0040-1951(92)90316-X. 
Cruden, A.R., 1998, On the emplacement of tabular granites: Journal of the Geological Society, v. 155 , p. $853-862$.

Cruden, A.R., 2006, Emplacement and growth of plutons: Implications for rates of melting and mass transfer in continental crust, in Brown, M., and Rushmer, T., eds., Evolution and Differentiation of the Continental Crust: New York, Cambridge University Press, p. 455-519.

Cruden, A.R., and McCaffrey, K.F.W., 2001, Growth of plutons by floor subsidence: Implications for rates of emplacement, intrusion spacing and meltextraction mechanisms: Physics and Chemistry of the Earth, v. 26, p. 303315, doi:10.1016/S1464-1895(01)00060-6.

Delaney, P.T., and Pollard, D.D., 1981, Deformation of host rocks and flow of magma during growth of minette dikes and breccia-bearing intrusions near Ship Rock, New Mexico: U.S. Geological Survey Professional Paper 1202, 61 p.

de Saint Blanquat, M., Law, R.D., Bouchez, J.-L., and Morgan, S.S., 2001, Internal structure and emplacement of the Papoose Flat pluton: An integrated structural, petrographic, and magnetic susceptibility study: Geological Society of America Bulletin, v. 113, p. 976-995, doi:10.1130/0016-7606(2001)113< 0976:ISAEOT>2.0.CO;2.

de Saint Blanquat, M., Horsman, E., Habert, G., Morgan, S., Vanderhaeghe, O., Law, R., and Tikoff, B., 2011, Multiscale magmatic cyclicity, duration of pluton construction, and the paradoxical relationship between tectonism and plutonism in continental arcs: Tectonophysics, v. 500, p. 20-33, doi:10.1016 /j.tecto.2009.12.009.

Druitt, T.H., Costa, F., Deloule, E., Dungan, M., and Scaillet, B., 2012, Decadal to monthly timescales of magma transfer and reservoir growth at a caldera volcano: Nature, v. 482, p. 77-80, doi:10.1038/nature10706.

Glazner, A.F., Bartley, J.M., Coleman, D.S., Gray, W., and Taylor, R.Z., 2004, Are plutons assembled over millions of years by amalgamation from small magma chambers?: GSA Today, v. 14, p. 4-11, doi:10.1130/10525173(2004)014<0004:APAOMO>2.0.CO;2.

Gualda, G.A.R., Pamukcu, A.S., Ghiorso, M.S., Anderson, A.T., Jr., Sutton, S.R., and Rivers, M.L., 2012, Timescales of quartz crystallization and the longevity of the Bishop giant magma body: PLoS ONE, v. 7, e37492, doi:10.1371 /journal.pone.0037492.

Hawkes, L., and Hawkes, H.K., 1933, The Sandfell Laccolith and 'Dome of Elevation': Quarterly Journal of the Geological Society, v. 89, p. 379-400, doi:10.1144/GSL.JGS.1933.089.01-04.14.

Heimpel, M., and Olson, P., 1994, Buoyancy-driven fracture and magma transport through the lithosphere: Models and experiments, in Ryan, M.P., ed., Magmatic Systems: San Diego, California, Academic Press, p. 223-240.

Horsman, E., Morgan, S., de Saint Blanquat, M., Habert, G., Nugnet, A., Hunter, R.A., and Tikoff, B., 2009, Emplacement and assembly of shallow intrusions from multiple magma pulses, Henry Mountains, Utah: Earth and Environmental Science Transactions of the Royal Society of Edinburgh, v. 100, p. 117-132, doi:10.1017/S1755691009016089.

Jellinek, A.M., and DePaolo, D.J., 2003, A model for the origin of large silicic magma chambers: Precursors of caldera-forming eruptions: Bulletin of Volcanology, v. 65, p. 363-381, doi:10.1007/s00445-003-0277-y.

Kojitani, H., and Akaogi, M., 1994, Calorimetric study of olivine solid solutions in the system $\mathrm{Mg}_{2} \mathrm{SiO}_{4}-\mathrm{Fe}_{2} \mathrm{SiO}_{4}$ : Physics and Chemistry of Minerals, v. 20, p. 536-540, doi:10.1007/BF00211849.

Lange, R.A., Cashman, K.V., and Navrotsky, A., 1994, Direct measurements of latent heat during crystallization and melting of a ugandite and an olivine basalt: Contributions to Mineralogy and Petrology, v. 118, p. 169-181, doi:10.1007/BF01052867.

Leuthold, J., Müntener, O., Baumgartner, L.P., Putlitz, B., Ovtcharova, M., and Schaltegger, U., 2012, Time resolved construction of a bimodal laccolith (Torres del Paine, Patagonia): Earth and Planetary Science Letters, v. 325326, p. 85-92, doi:10.1016/j.eps1.2012.01.032.

Lister, J.R., and Kerr, R.C., 1991, Fluid-mechanical models of crack propagation and their application to magma transport in dikes: Journal of Geophysical Research, v. 96, p. 10,049-10,077, doi:10.1029/91JB00600.
Martin, V.M., Morgan, D.J., Jerram, D.A., Caddick, M.J., Prior, D.J., and Davidson, J.P., 2008, Bang! Month-scale eruption triggering at Santorini volcano: Science, v. 321, p. 1178, doi:10.1126/science.1159584.

Menand, T., Annen, C., and de Saint Blanquat, M., 2011, Emplacement of magma pulses and growth of magma bodies: Tectonophysics, v. 500, p. 1-2, doi:10.1016/j.tecto.2010.05.014.

Michel, J., Baumgartner, L., Putlitz, B., Schaltegger, U., and Ovtcharova, M., 2008, Incremental growth of the Patagonian Torres del Paine laccolith over 90 k.y.: Geology, v. 36, p. 459-462, doi:10.1130/G24546A.1.

Mysen, B.O., 1981, Melting curves of rocks and viscosity of rock-forming melts, in Touloukian, Y.S., et al., eds., Physical Properties of Rocks and Minerals (Data Series on Material Properties 2): New York, McGraw-Hill/CINDAS, p. 361-407.

Parks, M.M., et al., 2012, Evolution of Santorini volcano dominated by episodic and rapid fluxes of melt from depth: Nature Geoscience, v. 5, p. 749-754, doi:10.1038/ngeo1562.

Petford, N., Kerr, R.C., and Lister, J.R., 1993, Dike transport in granitoid magmas: Geology, v. 21, p. 845-848, doi:10.1130/0091-7613(1993)021<0845: DTOGM $>2.3 . \mathrm{CO} ; 2$.

Petford, N., Cruden, A.R., McCaffrey, K.J.W., and Vigneresse, J.-L., 2000, Granite magma formation, transport and emplacement in the Earth's crust: Nature, v. 408, p. 669-673, doi:10.1038/35047000.

Piwinskii, A.J., and Wyllie, P.J., 1968, Experimental studies of igneous rock series: A zoned pluton in the Wallowa Batholith, Oregon: The Journal of Geology, v. 76, p. 205-234, doi:10.1086/627323.

Reiter, M., Chamberlin, R.M., and Love, D.W., 2010, New data reflect on the thermal antiquity of the Socorro magma body locale, Rio Grande Rift, New Mexico: Lithosphere, v. 2, p. 447-453, doi:10.1130/L115.1.

Remy, D., Froger, J.L., Perfettini, H., Bonvalot, S., Gabalda, G., Albino, F., Cayol, V., Legrand, D., and de Saint Blanquat, M., 2014, Persistent uplift of the Lazufre volcanic complex (Central Andes): New insights from PCAIM inversion of InSAR time series and GPS data: Geochemistry Geophysics Geosystems, v. 15, p. 3591-3611, doi:10.1002/2014GC005370.

Robertson, E.C., 1988, Thermal properties of rocks: U.S. Geological Survey Open-File Report 88-441, 110 p.

Rubin, A.M., 1995, Getting granite dikes out of the source region: Journal of Geophysical Research, v. 100, p. 5911-5929, doi:10.1029/94JB02942.

Schöpa, A., and Annen, C., 2013, The effects of magma flux variations on the formation and lifetime of large silicic magma chambers: Journal of Geophysical Research, v. 118, p. 926-942, doi:10.1002/jgrb.50127.

Spence, D.A., and Turcotte, D.L., 1985, Magma-driven propagation of cracks: Journal of Geophysical Research, v. 90, p. 575-580, doi:10.1029/JB090iB01p00575.

Spera, F.J., 2000, Physical properties of magmas, in Sigurdsson, H., et al., eds., Encyclopedia of Volcanoes: San Diego, California, Academic Press, p. 171-190.

Tanaka, A., and Ishikawa, Y., 2002, Temperature distribution and focal depth in the crust of the northeastern Japan: Earth, Planets, and Space, v. 54, p. 11091113, doi:10.1186/BF03353310.

Wagner, T.P., Donnelly-Nolan, J.M., and Grove, T.L., 1995, Evidence of hydrous differentiation and crystal accumulation in the low- $\mathrm{MgO}$, high- $\mathrm{Al}_{2} \mathrm{O}_{3}$ Lake Basalt from Medicine Lake volcano, California: Contributions to Mineralogy and Petrology, v. 121, p. 201-216, doi:10.1007/s004100050099.

Whittington, A.G., Hofmeister, A.M., and Nabelek, P.I., 2009, Temperaturedependent thermal diffusivity of the Earth's crust and implications for magmatism: Nature, v. 458, p. 319-321, doi:10.1038/nature07818.

Manuscript received 27 August 2014

Revised manuscript received 9 December 2014

Manuscript accepted 10 December 2014

Printed in USA 
2 GSA Supplemental information

3 Supplemental information for: Rates of magma transfer in the crust: insights into magma 4 reservoir recharge and pluton growth by Thierry Menand, Catherine Annen, and Michel de Saint 5 Blanquat.

\section{STEADY-STATE PROPAGATION OF A BUOYANCY-DRIVEN DYKE}

Whether fed by a constant flux or a constant pressure from its source, a vertically

8 propagating buoyant dyke will ultimately reach the same steady state once its vertical extent

9 becomes greater than its buoyancy length $L_{b}=\left(\frac{K_{c}}{\Delta \rho g}\right)^{2 / 3}$ (Lister and Kerr, 1991; Menand and

10 Tait, 2002), where $K_{c}$ is the fracture toughness of the country rocks, $\Delta \rho$ is the density

11 difference between country rocks and magma, and $g$ is the gravitational acceleration. This

12 steady state is characterised by a constant vertical velocity and a constant volumetric flow rate

13 (Lister and Kerr, 1991; Menand and Tait, 2002). Importantly, the steady-state dyke geometry is also characterised by a constant thickness $\boldsymbol{w}$ away from its propagating upper tip, at a distance greater than $\sim \mathbf{4} L_{\boldsymbol{b}}$ (Lister, 1990), determined by the constant incoming flux of magma delivered by its feeding source. For the vast majority of dykes, magma flow is laminar and the steady-state dyke thickness depends on the magma viscosity $\boldsymbol{\mu}$, the density difference between country rocks and magma $\Lambda \rho$, the gravitational acceleration $g$, the dyke horizontal extent $B$ and the average volumetric magma flow rate $Q$ as $w=\left(\frac{12 \mu Q}{\Lambda \rho g B}\right)^{1 / 3}$ (Lister and Kerr, 1991). The average volumetric magma flow rate can thus be expressed as a function of the other parameters: $Q=\frac{\Delta \rho g w^{3} B}{12 \mu}$. (DR1)

Another characteristic feature of a steadily propagating buoyant dyke is that its horizontal dimension $B$ is approximately constant and equal to the buoyancy length of the dyke (Menand and Tait, 2001; 2002): $B \approx\left(\frac{K_{c}}{\Delta \rho g}\right)^{2 / 3}$. There is presumably a constant of proportionality between

25 the horizontal dimension $B$ and the buoyancy length $L_{b}$ depending on the exact shape of the dyke, but this shape factor will most likely remain of order one. Moreover, the variability in horizontal dimension will be most affected by the range of possible values in both the rock fracture toughness $K_{c}$ and the density difference $\Delta \rho$ between magma and country rocks. [In the case the host rock has a negligible fracture toughness, the horizontal dimension of a buoyant dyke will instead increase with the distance $z$ above its source as $z^{3 / 10}$, however for the range of fracture-toughness values considered in Table 1 this horizontal spread of the dyke will be

32 prevented (Lister and Kerr, 1991).] 
10000 Monte-Carlo simulations with values for $K_{c}$ and $\Lambda \rho$ sampled randomly within the ranges of values listed in Table 1 give an overall range of horizontal dimensions $B$ between 400 m and $200 \mathrm{~km}$ with $80 \%$ of the $B$ values smaller than $20 \mathrm{~km}$, a mean value of $\sim 13 \mathrm{~km}$ and a mode value of $\sim 5 \mathrm{~km}$ (Fig. DR1). These calculated values are in excellent agreement with observed dyke dimensions, and thus suggest the scaling law used for $B$ captures the appropriate range of geological dimensions. The average volumetric magma flow rate in a vertically propagating steady-state buoyant dyke can thus be expressed as

$$
Q=\frac{\Delta \rho g w^{3}}{12 \mu}\left(\frac{K_{c}}{\Delta \rho g}\right)^{2 / 3} \text {. (DR2) }
$$

\section{CRITICAL MINIMUM MAGMA FLOW RATE}

In order to be able to propagate over some distance $H$, a dyke must have a critical minimum thickness $w_{c}$ so that magma may ascend through the crust over this distance without freezing (Petford et al., 1993):

$$
w_{c}=1.5\left[\frac{C_{p}\left(T_{f}-T_{\infty}\right)^{2}}{L\left(T_{0}-T_{f}\right)}\right]^{3 / 4}\left(\frac{\mu \kappa H}{\Delta \rho g}\right)^{1 / 4} \cdot(\mathrm{DR} 3)
$$

$L$ is magma latent heat, $C_{p}$ is its specific heat capacity, $T_{o}, T_{f}$ and $T_{\text {o }}$ are the initial magma, freezing and crustal far-field temperatures, respectively, $\mu$ is magma dynamic viscosity, $\kappa$ is its thermal diffusivity, $\Delta \rho$ is the density difference between country rocks and magma, and $g$ is gravitational acceleration. Dykes that are thinner than this critical thickness freeze before they could propagate as far as the distance $H$ whereas thicker dykes could propagate even further, and even possibly melt some of the country rocks (Bruce and Huppert, 1989).

Although Equation (DR3) gives the minimum thickness a dyke must have to be thermally able to transport magma over some distance in the crust, this equation does not provide any constraint on the dyke dynamics. Indeed, dykes of the same thickness could a priori involve different magma fluxes, hence different amounts of advected heat. Considering magma flow as laminar and buoyancy-driven within a dyke of thickness $\boldsymbol{w}$ and intruding rocks of fracture toughness $K_{c}$, the magma average volumetric flow rate is given by Equation (DR2), $Q=\frac{\Delta \rho g w^{3}}{12 \mu}\left(\frac{K_{c}}{\Delta \rho g}\right)^{2 / 3}$. Combining this expression with Equation (DR3) yields the magma volumetric flow rate in a dyke with the critical thickness $w_{c}$ :

$$
Q_{c}=\frac{9}{32}\left[\frac{C_{p}\left(T_{f}-T_{\infty}\right)^{2}}{L\left(T_{0}-T_{f}\right)}\right]^{9 / 4}\left(\frac{\Delta \rho g \kappa^{3} H^{3}}{\mu}\right)^{1 / 4}\left(\frac{K_{c}}{\Delta \rho g}\right)^{2 / 3}
$$

This critical magma supply rate $Q_{c}$ is the volumetric flow rate that allows a dyke to propagate over a distance $H$ without freezing.

A counterintuitive result is that this critical, minimum flux decreases with magma viscosity: more viscous dykes can flow at lower fluxes and not freeze. The key point here is that both the volumetric flux in a dyke, $Q$, and the critical dyke thickness, $w_{c}$, depend on the magma viscosity but the flux itself does depend also on the thickness: the flux in a buoyant dyke is 
viscosity, $Q \alpha w^{3} \mu^{-1}$, (Equation DR2). We are dealing with the minimum volumetric flux that would allow a buoyant dyke to propagate over a given distance, and so this flux must be associated with the critical thickness of that dyke, $Q_{c} \alpha w_{c}^{3} \mu^{-1}$. Because the critical thickness varies as the magma viscosity to the 1/4th power (Equation DR3), $w_{c} \alpha \mu^{1 / 4}$, the combine effect of this dependency with that of the flux leads to the minimum flux as decreasing with the magma viscosity to the $1 / 4$ th power, $Q_{c} \alpha \mu^{-1 / 4}$. In other words, fluid dynamics dictate that more viscous magmas induce thicker dykes (Equation DR2), and because thicker dykes cool more slowly the net effect is a lower minimum supply rate (Equation DR4). We note, however, that this dependency results in a minimal effect of magma viscosity on the critical, minimum flux $Q_{c}$ : an increase of viscosity by eight orders of magnitude will reduce the minimum flux by only a factor 100.

\section{PARAMETER RANGES AND DISTRIBUTIONS IN MONTE CARLO SIMULATIONS}

The ranges of parameters used in the Monte Carlo simulations were taken from the following references: Latent heat $L$ from Bohrson and Spera (2001), Kojitani and Akaogi (1994), and Lange et al. (1994); specific heat $C_{p}$ from Bohrson and Spera (2001) and Robertson (1988); thermal diffusivity $\kappa$ from Whittington et al. (2009); fracture toughness $K_{c}$ from Atkinson (1984), Delaney and Pollard (1981), and Heimpel and Olson (1994); density contrast $\Delta \rho$ from Spera (2000); initial magma temperature $T_{o}$ from Mysen (1981); difference between the initial and freezing magma temperatures $\Delta T_{i}$ from Piwinskii and Wyllie (1968), and Wagner et al. (1995).

For each parameter, there was not enough data to enable us to favour one particular distribution relative to others. A uniform distribution was therefore chosen as it gives the same weight to all data. The only exception is the rock fracture toughness $K_{c}$. There is a long debate as to its true representative values, with measurements from laboratory-scale rock samples giving values of about $10^{6} \mathrm{~Pa} \mathrm{~m}^{1 / 2}$ (Atkinson; 1984) while field-scale fracture toughness values can be 93 up to 3 orders of magnitude greater (Delaney and Pollard, 1981; Heimpel and Olson, 1994). Instead of arbitrarily favouring one set of values more than the other, we chose to sample the whole range with a log-normal distribution. This corresponded to sampling the exponent values between 6 and 9 with a normal distribution around a mean value of 7.5 that is comparable with both laboratory- and field-derived values. Furthermore, a log-normal distribution diminishes the weight attributed to extreme values, whether laboratory- or field-based, and leads to a range of values for the dyke breadth B in very good agreement with field observations as shown in Fig. DR1. 


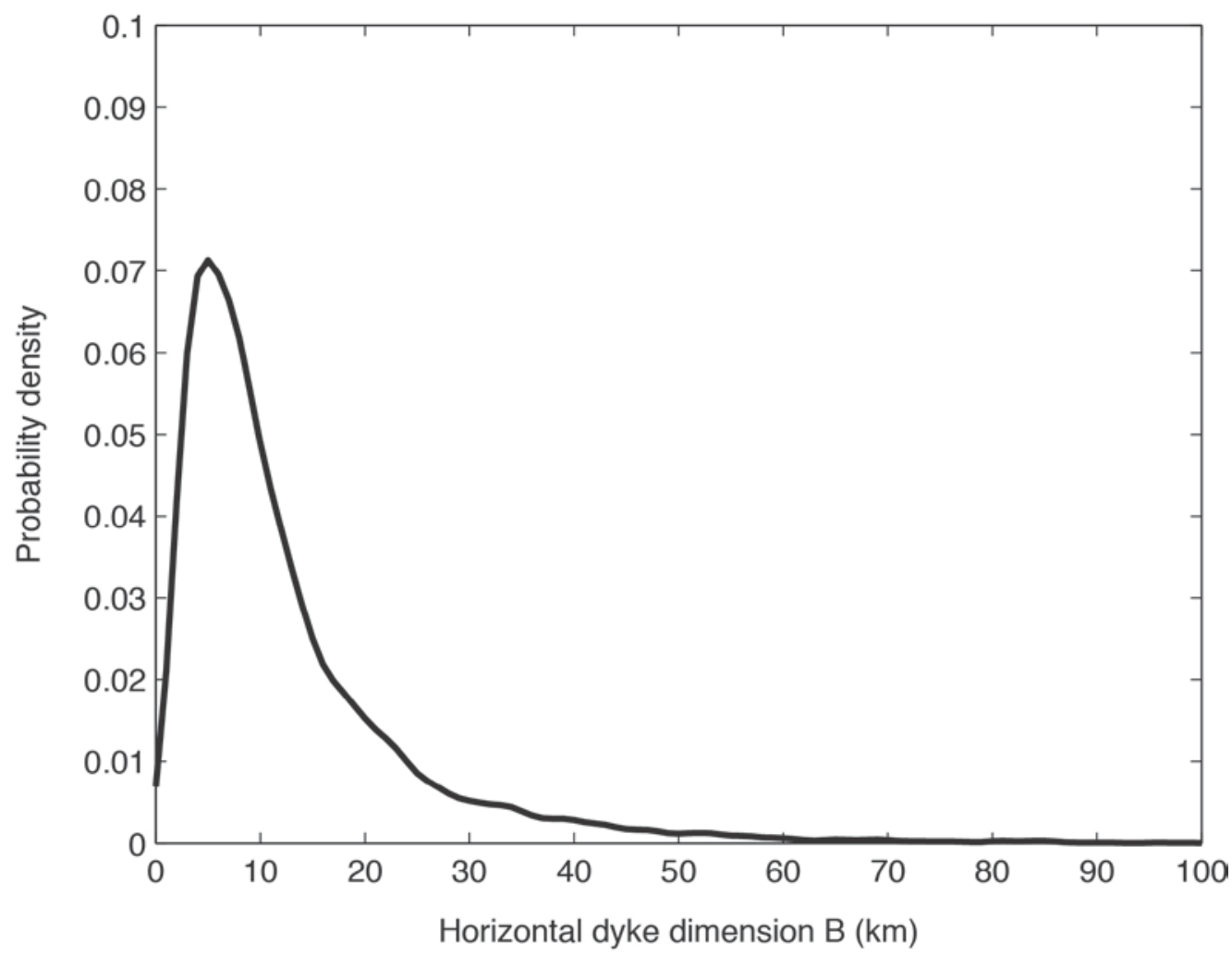

102 Figure DR1. Probability density estimate (normal kernel function) of 10000 Monte-Carlo 103 horizontal steady-state dimensions $B$ for a buoyancy-driven dyke (parameter ranges in Table 1 ).

104 TABLE DR1. ESTIMATES OF MAXIMUM, LONG-TERM AVERAGED, PLUTON105 FILING RATES.

\begin{tabular}{|c|c|c|}
\hline System & Max. long-term filling rate $\left(\mathrm{km}^{3} / \mathrm{yr}\right)$ & Method \\
\hline Boulder batholith $^{\mathrm{a}}$ & $6.3 \times 10^{-3}$ & Isotope \\
\hline New Guinea Highlands ${ }^{\mathrm{a}}$ & $4.7 \times 10^{-3}$ & isotope \\
\hline Guichon Creek batholith, B.C. ${ }^{\text {a }}$ & $2.1 \times 10^{-4}$ & isotope \\
\hline Sierra Nevada batholith ${ }^{\mathrm{a}}$ & $6.9 \times 10^{-4}$ & isotope \\
\hline Sierra Nevada batholith ${ }^{\mathrm{a}}$ & $1.9 \times 10^{-3}$ & isotope \\
\hline Sierra Nevada batholith $^{\mathrm{a}}$ & $6.8 \times 10^{-3}$ & isotope \\
\hline Sierra Nevada batholith ${ }^{\mathrm{a}}$ & $1.9 \times 10^{-3}$ & isotope \\
\hline Southern California batholith ${ }^{\mathrm{a}}$ & $6.9 \times 10^{-3}$ & isotope \\
\hline Alaska-Aleutian Range batholith ${ }^{\mathrm{a}}$ & $9.8 \times 10^{-3}$ & isotope \\
\hline New England batholith, Australia ${ }^{a}$ & $2.3 \times 10^{-3}$ & isotope \\
\hline Lachlan batholithic belt, Australia $^{\mathrm{a}}$ & $3.1 \times 10^{-3}$ & isotope \\
\hline Peruvian Coastal batholith ${ }^{\mathrm{a}}$ & $1.2 \times 10^{-2}$ & isotope \\
\hline Coast Range Plutonic Complex, B.C. ${ }^{a}$ & $1.4 \times 10^{-2}$ & isotope \\
\hline Black Mesa ${ }^{\mathrm{b}}$ & $5.0 \times 10^{-3}$ & thermal \\
\hline Papoose Flat ${ }^{\mathrm{C}}$ & $2.5 \times 10^{-2}$ & thermal \\
\hline Scuzzy $^{\mathrm{e}}$ & $3.0 \times 10^{-3}$ & isotope \\
\hline Socorro $^{\mathrm{f}}$ & $2.8 \times 10^{-1}$ & thermal \\
\hline Hualca Hualca $^{\mathrm{g}}$ & $2.5 \times 10^{-2}$ & deformation \\
\hline Uturuncu $^{\mathrm{g}}$ & $3.0 \times 10^{-2}$ & deformation \\
\hline Lazufre $^{\mathrm{g}}$ & $6.0 \times 10^{-3}$ & deformation \\
\hline Mt Stuart Batholith ${ }^{\mathrm{h}}$ & $2.2 \times 10^{-4}$ & isotope \\
\hline Mt Stuart Batholith old domain ${ }^{\mathrm{h}}$ & $5.8 \times 10^{-4}$ & isotope \\
\hline Mt Stuart Batholith young domain ${ }^{\mathrm{h}}$ & $3.1 \times 10^{-3}$ & isotope \\
\hline Tenpeak intrusion ${ }^{\mathrm{h}}$ & $1.5 \times 10^{-4}$ & isotope \\
\hline Geyser-Cobb Mountain ${ }^{\mathrm{i}}$ & $1.5 \times 10^{-3}$ & isotope \\
\hline Wiborg batholith ${ }^{\mathrm{j}}$ & $3.6 \times 10^{-3}$ & isotope \\
\hline Wiborg batholith ${ }^{\mathrm{j}}$ & $6.0 \times 10^{-3}$ & isotope \\
\hline
\end{tabular}




\begin{tabular}{|c|c|c|}
\hline Nain plutonic suite $^{k}$ & $4.8 \times 10^{-3}$ & isotope \\
\hline Nain plutonic suite ${ }^{\mathrm{k}}$ & $2.2 \times 10^{-3}$ & isotope \\
\hline Korosten complex ${ }^{1}$ & $4.0 \times 10^{-3}$ & isotope \\
\hline Korosten complex ${ }^{1}$ & $1.2 \times 10^{-2}$ & isotope \\
\hline Salmi complex ${ }^{\mathrm{m}}$ & $9.3 \times 10^{-3}$ & isotope \\
\hline Salmi complex ${ }^{\mathrm{m}}$ & $2.4 \times 10^{-3}$ & isotope \\
\hline Lastarria Cordon del Azufre ${ }^{\mathrm{n}, \mathrm{u}}$ & $1.4 \times 10^{-2}$ & deformation \\
\hline Torres del Paine (granite) ${ }^{\circ}$ & $8.0 \times 10^{-4}$ & isotope \\
\hline Torres del Paine (mafic) ${ }^{\circ}$ & $2.0 \times 10^{-4}$ & isotope \\
\hline Manaslu ${ }^{\mathrm{p}}$ & $6.0 \times 10^{-4}$ & thermal \\
\hline PX1, Fuerteventura ${ }^{\mathrm{q}}$ & $3.0 \times 10^{-4}$ & thermal \\
\hline Uturuncu $^{\mathrm{r}}$ & $1.0 \times 10^{-2}$ & deformation \\
\hline Spirit Mountain batholith ${ }^{\mathrm{s}, \mathrm{t}}$ & $1.3 \times 10^{-3}$ & isotope \\
\hline Usu-san ${ }^{\mathrm{v}}$ & $9.2 \times 10^{-1}$ & deformation \\
\hline Syowa Sinzan ${ }^{\mathrm{w}}$ & $2.1 \times 10^{-1}$ & deformation \\
\hline Lamark Granodiorite ${ }^{\mathrm{x}}$ & $2.0 \times 10^{-3}$ & isotope \\
\hline John Muir Intrusive Suite ${ }^{\mathrm{x}}$ & $1.0 \times 10^{-3}$ & isotope \\
\hline Rio Hondo ${ }^{y}$ & $2.7 \times 10^{-4}$ & isotope \\
\hline
\end{tabular}

106

107

108

109

110

These long-term-averaged pluton-filling-rate estimates assume no loss of material over time from the plutons, and reflect also the assumptions made by the various authors about their actual size and shape. a: Crisp (1984); b: Saint Blanquat et al. (2006); c: Saint Blanquat et al. (2001); d: Coleman et al. (2004); e: Brown and McClelland (2000); f: Pearse and Fialko (2010); g: Prittchard and Simmons (2002); h: Matzel et al. (2006); i: Schmitt et al. (2003); j: Vaasjoki et al. (1991); k: Emslie et al. (1994); l: Amelin et al. (1994); m: Amelin et al. (1997); n: Froger et al. (2007); o: Leuthold et al. (2012); p: Annen et al. (2006); q: Allibon et al. (2011); r: Sparks et al. (2008), s: Walker et al. (2007); t: Miller et al. (2011); u: Remy et al. (2014); v: Omori (1911); w: Minakami et al. (1951); x: Davis et al. (2012); y: Tappa et al. (2011).

\section{REFERENCES CITED}

Allibon, J., Bussy, F., Léwin, E., and Darbellay, B., 2011, The tectonically controlled emplacement of a vertically sheeted gabbro-pyroxenite intrusion: Feeder-zone of an oceanisland volcano (Fuerteventura, Canary Islands): Tectonophysics, v. 500, p. 78-97, doi:10.1016/j.tecto.2010.01.011.

Amelin, Y.V., Heaman, L.M., Verchogliad, V.M., and Skobelev, V.M., 1994, Geochronological constraints on the emplacement history of an anorthosite-rapakivi granite suite: $\mathrm{U}-\mathrm{Pb}$ zircon and baddeleyite study of the Korosten complex, Ukraine: Contributions to Mineralogy and Petrology, v. 116, p. 411-419, doi:10.1007/BF00310908.

Amelin, Y.V., Larin, A.M., and Tucker, R.D., 1997, Chronology of multiphase emplacement of the Salmi rapakivi granite-anorthosite complex, Baltic Shield: implications for magmatic evolution: Contributions to Mineralogy and Petrology, v. 127, p. 353-368, doi:10.1007/s004100050285.

Annen, C., Scaillet, B., and Sparks, R.S.J., 2006, Thermal constraints on the emplacement rate of a large intrusive complex: the Manaslu leucogranite, Nepal Himalaya: Journal of Petrology, v. 47, p. 71-95, doi:10.1093/petrology/egi068.

Atkinson, B.K., 1984, Subcritical crack growth in geological materials: Journal of Geophysical Research, v. 89, p. 4077-4114, doi:10.1029/JB089iB06p04077.

Bohrson, W.A., and Spera, F.J., 2001, Energy-constrained open-system magmatic processes II: Application of energy-constrained assimilation-fractional crystallization (EC-AFC) model to magmatic systems: Journal of Petrology, v. 42, p. 1019-1041, doi:10.1093/petrology/42.5.1019. 
Brown, E.H., and McClelland, W.C., 2000, Pluton emplacement by sheeting and vertical ballooning in part of the southeast Coast Plutonic Complex, British Columbia: Geological Society of America Bulletin, v. 112, p. 708-719, doi:10.1130/00167606(2000)112<708:PEBSAV>2.0.CO;2.

Bruce, P.M., and Huppert, H.H., 1989, Thermal control of basaltic eruptions: Nature, v. 342, p. 665-667, doi:10.1038/342665a0.

Coleman, D.S., Gray, W., and Glazner, A.F., 2004, Rethinking the emplacement and evolution of zoned plutons: Geochronologic evidence for incremental assembly of the Tuolumne Intrusive Suite, California: Geology, v. 32, p. 433-436.

Crisp, J.A., 1984, Rates of magma emplacement and volcanic output: Journal of Volcanology and Geothermal Research, v. 20, p. 177-211, doi:10.1016/0377-0273(84)90039-8.

Davis, J.W., Coleman, D.S., Gracely, J.T., Gaschnig, R., and Stearns, M., 2012, Magma accumulation rates and thermal histories of plutons of the Sierra Nevada batholith, CA: Contributions to Mineralogy and Petrology, v. 163, p. 449-465, doi:10.1007/s00410011-0683-7.

Delaney, P.T., and Pollard, D.D., 1981, Deformation of host rocks and flow of magma during growth of minette dikes and breccia-bearing intrusions near Ship Rock, New Mexico: U.S. Geological Survey Professional Paper 1202, 61 p.

Emslie, R.F., Hamilton, M.A., and Thériault, R.J., 1994, Petrogenesis of a Mid-Proterozoic Anorthosite-Mangerite-Charnockite-Granite (AMCG) complex: isotopic and chemical evidence from the Nain plutonic suite: The Journal of Geology, v. 102, p. 539-558, doi:10.1086/629697.

Froger, J.L., Remy, D., Bonvalot, S., and Legrand, D., 2007, Two scales of inflation at LastarriaCordon del Azufre volcanic complex, central Andes, revealed from ASAR-ENVISAT interferometric data: Earth and Planetary Science Letters, v. 255, p. 148-163, doi:10.1016/j.epsl.2006.12.012.

Heimpel, M., and Olson, P., 1994, Buoyancy-driven fracture and magma transport through the lithosphere: Models and experiments in Ryan, M.P., ed., Magmatic Systems: San Diego, Academic Press, p. 223-240.

Kojitani, H., and Akaogi, M., 1994, Calorimetric study of olivine solid solutions in the system Mg2SiO4-Fe2SiO4: Physics and Chemistry of Minerals, v. 20, p. 536-540, doi:10.1007/BF00211849.

Lange, R.A., Cashman, K.V., and Navrotsky, A., 1994, Direct measurements of latent heat during crystallization and melting of a ugandite and an olivine basalt: Contributions to Mineralogy and Petrology, v. 118, p. 169-181, doi:10.1007/BF01052867.

Leuthold, J., Müntener, O., Baumgartner, L.P., Putlitz, B., Ovtcharova, M., and Schaltegger, U., 2012, Time resolved construction of a bimodal laccolith (Torres del Paine, Patagonia): Earth and Planetary Science Letters, v. 325-326, p. 85-92, doi:10.1016/j.epsl.2012.01.032.

Lister, J.R., 1990, Buoyancy-driven fluid fracture: the effects of material toughness and of lowviscosity precursors: Journal of Fluid Mechanics, v. 210, p. 263-280, doi:10.1017/S0022112090001288.

Lister, J.R., and Kerr, R.C., 1991, Fluid-mechanical models of crack propagation and their application to magma transport in dykes: Journal of Geophysical Research, v. 96, B6, p. 10,049-10,077, doi:10.1029/91JB00600. 
Matzel, J.E.P., Bowring, S.A., and Miller, R.B., 2006, Time scales of pluton construction at differing crustal levels: Examples from the Mount Stuart and Tenpeak intrusions, North Cascades, Washington: Geological Society of America Bulletin, v. 118, p. 1412-1430, doi:10.1130/B25923.1.

Menand, T., and Tait, S.R., 2001, A phenomenological model for precursor volcanic eruptions: Nature, v. 411, p. 678-680, doi:10.1038/35079552.

Menand, T., and Tait, S.R., 2002, The propagation of a buoyant liquid-filled fissure from a source under constant pressure: An experimental approach: Journal of Geophysical Research, v. 107, B11, p. 2306, doi:10.1029/2001JB000589.

Minakami, T., Ishikawa, T., and Yagi, K., 1951, The 1944 eruption of volcano Usu in Hokkaido, Japan: Volcanological Bulletin, v. 11, p. 45-157, doi:10.1007/BF02596029.

Miller, C.F., Furbish, D.J., Walker, B.A., Claiborne, L.L., Koteas, G.C., Bleick, H.A., and Miller, J.S., 2011, Growth of plutons by incremental emplacement of sheets in crystalrich host: Evidence from Miocene intrusions of the Colorado River region, Nevada, USA: Tectonophysics, v. 500, p. 65-77, doi:10.1016/j.tecto.2009.07.011.

Mysen, B.O., 1981, Melting curves of rocks and viscosity of rock-forming melts, in Touloukian, Y.S., Judd, W.D., and Roy, R.F., eds., Physical Properties of rocks and minerals, Data series on material properties 2: New York, McGraw -Hill/CINDAS, p. 361-407.

Omori, F., 1911, The Usu-San eruption and earthquakes and elevation phenomena: Bulletin of the Imperial Earthquake Investigation Committee, v. 5, p. 1-38.

Pearse, J., and Fialko, Y., 2010, Mechanics of active magmatic intraplating in the Rio Grande Rift near Socorro, New Mexico: Journal of Geophysical Research, v. 115, p. B07413, doi:10.1029/2009JB006592.

Petford, N., Kerr, R.C., and Lister, J.R., 1993, Dike transport in granitoid magmas: Geology, v. 21, p. 845-848, doi:10.1130/0091-7613(1993)021<0845:DTOGM>2.3.CO;2.

Piwinskii, A.J., and Wyllie, P.J., 1968, Experimental studies of igneous rock series: A zoned pluton in the Wallowa Batholith, Oregon: The Journal of Geology, v. 76, p. 205-234, doi:10.1086/627323.

Prittchard, M.E., and Simmons, M., 2002, A satellite geodetic survey of large- scale deformation of volcanic centres in the central Andes: Nature, v. 418, p. 1-5.

Remy, D., Froger, J.L., Perfettini, H., Bonvalot, S., Gabalda, G., Albino, F., Cayol, V., Legrand, D., and Saint Blanquat (de), M., 2014, Persistent uplift of the Lazufre volcanic complex (Central Andes): new insights from PCAIM inversion of InSAR time series and GPS data: Geochemistry Geophysics Geosystems, doi:10.1002/2014GC005370.

Robertson, E.C., 1988, Thermal Properties of Rocks: U.S. Geological Survey Open-file Report 88-441, p. 1-110.

Saint Blanquat (de), M., Habert, G., Horsman, E., Morgan, S.S., Tikoff, B., Laneau, P., and Gleizes, G., 2006, Mechanisms and duration of non-tectonically assisted magma emplacement in the upper crust: The Black Mesa pluton, Henry Mountains, Utah: Tectonophysics, v. 428, p. 1-31.

Saint Blanquat(de), M., Law, R.D., Bouchez, J.-L., and Morgan, S.S., 2001, Internal structure and emplacement of the Papoose Flat pluton: An integrated structural, petrographic, and magnetic susceptibility study: Geological Society of America Bulletin, v. 113, p. 976-995, doi:10.1130/0016-7606(2001)113<0976:ISAEOT>2.0.CO;2.

Schmitt, A.K., Grove, M., Harrison, T.M., Lovera, O., Hulen, J., and Walters, M., 2003, The Geysers-Cobb Mountain Magma System, California (Part 2): timescales of pluton 
Sparks, R.S.J., Folkes, C., Humphreys, M., Barfod, D., Clavero, J., Sunagua, M., McNutt, S., and Pritchard, M., 2008, Uturuncu volcano, Bolivia: Volcanic unrest due to mid-crustal magma intrusion: American Journal of Science, v. 308, p. 727-769, doi:10.2475/06.2008.01. Spera, F.J., 2000, Physical properties of magmas, in Sigurdsson, H., Houghton, B., Rymer, H., Stix, J., and McNutt, S., eds., Encyclopedia of Volcanoes: San Diego, Academic Press, p. 171-190.

Tappa, M.J., Coleman, D.S., Mills, R.D., and Samperton, K.M., 2011, The plutonic record of a silicic ignimbrite from the Latir volcanic field, New Mexico: Geochemistry Geophysics Geosystems, v. Q10011, doi:10.1029/2011GC003700.

Vaasjoki, M., Rämö, O.T., and Sakko, M., 1991, New U-Pb ages from the Wiborg rapakivi area: constraints on the temporal evolution of the rapakivi granite-anorthosite-diabase dyke association of southeastern Finland: Precambrian Research, v. 51, p. 227-243, doi:10.1016/0301-9268(91)90102-G.

Wagner, T.P., Donnelly-Nolan, J.M., and Grove, T.L., 1995, Evidence of hydrous differentiation and crystal accumulation in the low-MgO, high-Al2O3 Lake Basalt from Medicine Lake volcano, California: Contributions to Mineralogy and Petrology, v. 121, p. 201-216, doi:10.1007/s004100050099.

Walker Jr, B.A., Miller, C.F., Lowery Claiborne, L., Wooden, J.L., and Miller, J.S., 2007, Geology and geochronology of the Spirit Mountain batholith, southern Nevada: Implications for timescales and physical processes of batholith construction: Journal of Volcanology and Geothermal Research, v. 167, p. 239-262, doi:10.1016/j.jvolgeores.2006.12.008.

Whittington, A.G., Hofmeister, A.M., and Nabelek, P.I., 2009, Temperature-dependent thermal diffusivity of the Earth's crust and implications for magmatism: Nature, v. 458, p. 319-321, doi:10.1038/nature07818. 